九州大学学術情報リポジトリ

Kyushu University Institutional Repository

\title{
The Potential Mapping of Land Fire Using SNPP VIIRS as a Basis for Environmental Damage Mitigation
}

Kuma lawat i, Rosalina

Department of Geography, Lambung Mangkurat University

Yuliarti, Astinana

Department of Communication Science, Lambung Mangkurat University

Rizky Nurita Anggraeni

Student of Department of Geography, Lambung Mangkurat University

Karnanto Hendra Mur Liawan

Ministry of Agrarian \& Spatial Plan/National Land Agency

https://doi.org/10.5109/4491638

出版情報：Evergreen. 8 (3)，pp.524-534，2021-09. 九州大学グリーンテクノロジー研究教育センター バージョン：

権利関係 : 


\title{
The Potential Mapping of Land Fire Using SNPP VIIRS as a Basis for Environmental Damage Mitigation
}

\author{
Rosalina Kumalawati ${ }^{1, *}$, Astinana Yuliarti ${ }^{2}$, Rizky Nurita Anggraeni ${ }^{3}$, \\ Karnanto Hendra Murliawan ${ }^{4}$ \\ ${ }^{1}$ Department of Geography, Lambung Mangkurat University, Indonesia \\ ${ }^{2}$ Department of Communication Science, Lambung Mangkurat University, Indonesia \\ ${ }^{3}$ Student of Department of Geography, Lambung Mangkurat University, Indonesia \\ ${ }^{4}$ Ministry of Agrarian \& Spatial Plan/National Land Agency, Indonesia \\ *Author to whom correspondence should be addressed: \\ E-mail: rosalina.kumalawati@ulm.ac.id
}

(Received April 26, 2020; Revised July 26, 2021; accepted September 10, 2021).

\begin{abstract}
Hotspot distribution area is very important to know, in order to anticipate and minimize the risk of fire. The research objective is The Potential Mapping of Land Fires Using SNPP VIIRS. The research used a survey method to collect data. Data processing techniques using ArcGIS software with scoring, overlay and clustering techniques. The highest number of hotspots in South Kalimantan is in Banjar Regency, with 17428 including low confidence (1303), nominal confidence (15444) and high confidence (681). The results of the mapping of existing Fire Potentials can be used as a basis for mitigation actions and providing recommendations for disaster management to reduce the risk of increasing environmental damage in the future.
\end{abstract}

Keywords: Hotspot, fire potential; SNPP VIIRS; mitigation; environmental damage

\section{Introduction}

Indonesia is a tropical country, an agricultural country and a developing country with a tropical climate ${ }^{1,2), 3}$, and climate change has also resulted in warmer temperatures, high frequency in low areas ${ }^{4)}$. Tropical regions are prone to disasters, including forest and land fire disasters. Freshwater supply is an emerging critical condition, a problem faced by many countries in the world ${ }^{5)}$, where the lack of water discharge also affects soil conditions which in turn support fires. Forest and land fires are environmental problems that occur in developed and developing countries ${ }^{6}$. Forest and land fires that occur in developing countries such as Indonesia ${ }^{7}$. Fires occurred in several regions in Indonesia, such as Sumatra and Kalimantan, which attracted worldwide attention because the smoke haze pollution reached neighboring countries. Forest fires are not new to Indonesia's forests and are an essential environmental problem ${ }^{8), 9}$. Forest and land fires occur due to 2 (two) main factors, namely natural factors and uncontrolled human activity factors ${ }^{3}$. Theoretically, fires occur because of the interaction between fuel, oxygen ignition; for example, the heat under certain conditions is one of the sources of ignition ${ }^{6}$. Fires that often occur over a long period time do not only burn forests and vegetation but also change existing structures such as climatic and soil conditions ${ }^{10)}{ }^{11}$ ).
Every year, reports show an increase in the number of people, population, urbanization, and industrialization, and these have a profound effect on the environmental conditions in which humans live ${ }^{12)}$. Population pressure on land is increasing, resulting in massive land clearing. Land clearing is one of the causes of fire disasters. Fire is a disaster that makes environmental conditions even more threatened because it can cause damage and environmental problems ${ }^{13), 14)}$. Forest fires and peatland conversion (plantations, agriculture and mining) are among the main factors causing environmental damage ${ }^{15)}$, 16). The conversion of peatlands for mining is considered a major contributor to pollutants that can trigger environmental damage ${ }^{17)}$, especially if the mining burns too. Meanwhile, the conversion of peatlands for plantations and agriculture has resulted in land degradation ${ }^{18), 19)}$. Degradation of peatlands due to human activities causes a decrease in productivity ${ }^{20}$. Degraded peatlands have a lower water holding capacity ${ }^{21), 22)}$, so that it is prone during the rainy season, to flooding and in the dry season it is prone to dryness and burns. Fires not only deplete the peat layer, thus accelerating the emergence of nutrient-poor mineral soil layers, but also cause pollution through the production of greenhouse gases (GHG) due to the release of carbon in the form of 
$\mathrm{CO} 2$, and this causes dangerous things and becomes a disaster for the individual ${ }^{23}$.

Indonesia's peatlands create the perfect storage system for locking in carbon dioxide that contributes to climate change. When cleared by burning peatlands, they release emissions. The emissions cast when peatlands are cleared and burned for agriculture or oil palm are very large and will affect aerosols in the atmosphere ${ }^{16)}{ }^{24)}$. An instance growing e gas emissions, particularly $\mathrm{CO} 2$, has been a global environmental issue that demands distinctive and practical actions to overcome ${ }^{25}$ ). Atmospheric aerosols are an important element of the atmosphere and have a direct influence on climate, weather, the hydrological cycle, and human health 24), 7),26),27),28),29). Disturbed aerosols and loss of carbon in peatlands due to peat conversion result in environmental damage. Seeing this, environmentally-friendly management is needed to reduce environmental damage ${ }^{30}$.

Environmental damage due to existing fires causes enormous losses ${ }^{31)}$. The environmental damage that occurs cannot be taken lightly or left unchecked. If environmental damage is not prevented and controlled, it will disrupt the balance of the ecosystem and human activities. Disrupted human activities cause enormous problems in various aspects, ranging from health aspects, social aspects and economic aspects ${ }^{32)}$. Disturbed ecosystem balance will trigger environmental issues. Environmental issues that arise due to fire are caused by human behavior and culture, so environmental ethics are needed ${ }^{33), 34}$. Culture can include all the institutionalized ways and implicit beliefs, norms, values and places that emphasize and influence behavior ${ }^{35), 36)}$. Environmental ethics is important because it will move humans to selfregulate so that they care about environmental sustainability. In addition to the need for environmental ethics, it is also necessary to mitigate environmental damage.

Mitigation is very necessary because the fire's impact is very bad for the environment around the fire location. Seeing this requires information to prevent fires from an early age through hotspot detection. Hotspot detection on the earth's surface from satellites is vital because it dramatically affects global ecology and climate ${ }^{37), 38), 39), 40 \text {. }}$ Early fire detection can be done by utilizing remote sensing satellite data. It can use remote sensing satellite data to detect hotspot data. Hotspot data in Indonesia significantly monitors the accuracy of potential forest and land fires ${ }^{41)}$.

Satellite data used to monitor hotspots and fire smoke

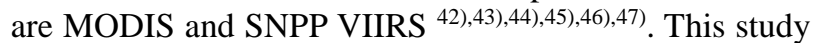
took hotspot data from SNPP VIIRS because the VIIRS System can detect hotspots better than the MODIS system; the VIIRS resolution is $375 \mathrm{MX} 375 \mathrm{~m}$, seven times smoother than MODIS $(1 \mathrm{~km} \times 1 \mathrm{~km})^{45), 48}$. Hotspot information is presented daily, which users can access via https://earthdata.nasa.gov/earth-observation-data/nearreal-time/firms/viirs-i-band-active-fire-data. The SNPP
VIIRS satellite will provide an overview of hotspots in forest and land fire areas as seen from the highest temperature in each fire area. The number of hotspots obtained is not the same as the number of forest and land fire incidents in the field ${ }^{49}$ ). Each hotspot monitored via remote sensing satellites has a confidence interval. The higher the resulting confidence interval, the higher the potential for a hotspot to become a fire ${ }^{43,50)}$.

Remote sensing satellite data obtained can be processed on a large scale and can be clustered ${ }^{51), 52)}$. The clustering principle is to maximize the similarity between members of one cluster and minimize similarity between members of different collections ${ }^{53)}$. Data are grouped based on common characteristics. Data with additional features will be grouped into other clusters / groups to determine areas that have the potential for fire ${ }^{54), 55)}$.

Through the SNNP VIIRS data, we can also find out the frequency and distribution of existing hotspots. VIIRS is able to detect every hotspot in the cluster which results in a higher number of hotspots ${ }^{56)}$. The frequency and distribution of hotspots need to be known for Potential Mapping Fires. Potential mapping for fires can be used as an initial step in mitigating the environmental damage caused by fires ${ }^{33)}$. Seeing this, it is necessary to research with the title "The Potential Mapping of Land Fire Using SNPP VIIRS for Environmental Damage Mitigation". It explored South Kalimantan because most districts / cities have a high number of hotspots; the highest is in Banjar Regency, South Kalimantan (see Figure 1).

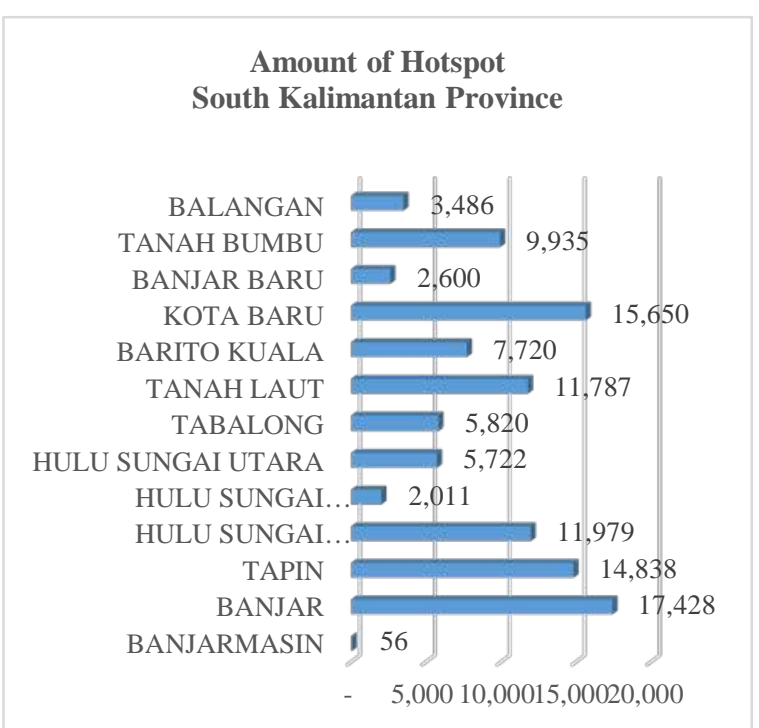

Fig. 1: Distribution of Hotspots from SNPP VIIRS in South Kalimantan, 2012-2021

Based on the chart above, it will also illustrate the objective of the research, namely mapping the potential for fires as an effort to mitigate environmental damage which is the effect of land fires, with the detection of hotspots in the Banjar Regency area through the SNPP VIIRS application, there will be preventive measures that 
can be taken to prevent the turning of what points into large fires that have the potential for land fires.

\section{Materials and Methods}

\subsection{Study Area}

Climate change is a strategic issue and a severe problem globally, including in Indonesia, due to global warming and depletion of the ozone layer 47),57). The existing climate change will impact the environment, such as the emergence of various environmental problems. One of the actual impacts of climate change are global warming and forest fire disasters caused by hot weather and rainfall 30),58),59). Another problem that also affects is related to environmental pollution ${ }^{60)}$. Carbon dioxide (CO2) has become a focus of scientific attention as its emissions are considered the main reason for climate change and the global warming effect ${ }^{61)}$.

Global warming is one of the significant climate changes, representing a gradual increase from the global average temperature mainly due to greenhouse gases (GHG), such as carbon dioxide (CO2), methane ( $\mathrm{CH} 4)$, nitrous oxides (N2O), ozone (O3), and chlorofluorocarbons (CFC) ${ }^{62)}$. Forest fires release methane gas, a greenhouse gas that is 21 times more toxic than carbon dioxide (CO2), but peat fires can emit ten times more methane than fires on other types of land. Methane gas has a more significant global warming potential, so that it will have a large enough impact on environmental damage ${ }^{63)}$. A pro-active adaptation strategy is needed rather than reactive policies to climate change to reduce environmental problems that arise ${ }^{64)}$.

Forest and land fires are critical environmental problems in Indonesia. Forest and land fires can steal the government's attention, so it is necessary to establish a policy as a strenuous effort to handle it. The government made serious efforts to declare it a national disaster to receive special from all elements.

Forest and land fires occur every year in Indonesia due to of various factors and are not a new phenomenon ${ }^{65), 66)}$. The incidence of fire each year continues to increase and is increasingly widespread ${ }^{67)}$. Forest and land fires since 1982/1983 when an estimated 3.6 million ha of tropical rainforest in East Kalimantan caught fire. The fires continued to recur from 1987 to 2021. The 2015 fires were the worst fire incidents caused by extreme weather events such as El Nino ${ }^{68)}$, ${ }^{69)}$.

El Nino is a natural factor in fire that causes prolonged drought, which causes plants to dry out. Dry plants are potential fuel if exposed to sparks. Apart from biological factors, fire is also caused by human activities, including land clearing activities, throwing cigarette butts carelessly, burning deliberately for housing and agriculture ${ }^{3)}$. Forest and land fires in Kalimantan are primarily the result of human activities related to forest deforestation (oil palm, pulp and paper plantations), land-use change, preparation of agricultural production by burning land ${ }^{38)}{ }^{66)}{ }^{70)}$. The
Practice of agricultural production by burning land is increasing, especially in agricultural countries with low economic levels ${ }^{21)}$. The massive burning of land carried out by the community to obtain economic benefits is an important element that further triggers fires.

The fire that occurs can trigger environmental damage. The impact of fires experienced is at the local level and global environment, so mitigation and adaptation is needed ${ }^{71), 72)}$. An essential component in mitigating fire events requires an early warning system. Early warning systems are a vital element in preventing forest and land fires ${ }^{73)}$. The development of an early warning system and a fire risk evaluation study are quite effective in preventing fires ${ }^{74)}$.

Through the detection of hotspot distribution, it can identify the location of potential fire events ${ }^{55)},{ }^{75)},{ }^{76)},{ }^{77)},{ }^{78)}$; Hotspots are an indication of a possible fire, Hotspots are an indication of the possibility of fire in an area. Hotspots have a relatively higher surface temperature than the surrounding area based on certain temperature thresholds monitored by remote sensing satellites. The more hotspots observed by satellite, the more potential fire is in an area ${ }^{(102)}$. Hotspots can be detected using remote sensing satellite data. Satellite data used to monitor hotspots and fire smoke is MODIS and SNPP VIIRS 19) ${ }^{44)}{ }^{79)}$. This research uses SNPP VIIRS to monitor the frequency and distribution of hotspots ${ }^{18)}$, but a large number of hotspots does not always reflect the more enormous the burned area ${ }^{80}$ ). The results of the frequency and distribution of hotspots using SNPP VIIRS will be processed into a Fire Potential Map (see Figure 2). The Fire Potential Map is the first step in estimating areas that have the potential for forest/land fires so that mitigation can be carried out ${ }^{33)}{ }^{81)}$. Mitigation carried out is the mitigation of environmental damage due to fire.

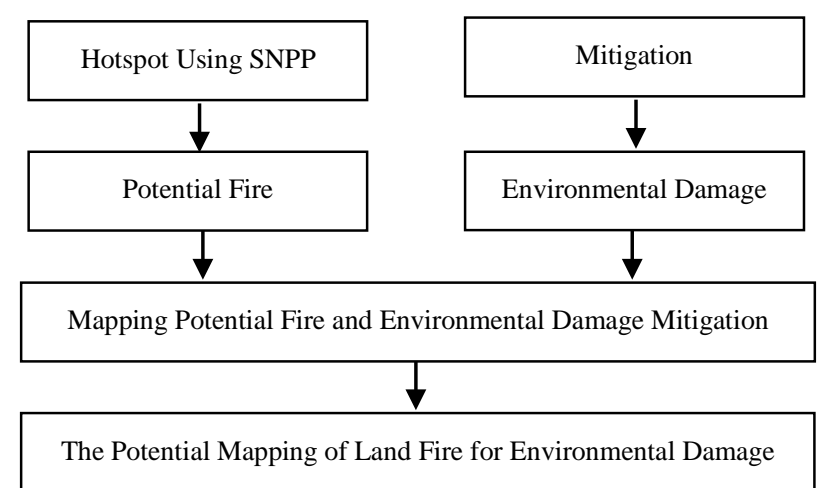

Fig. 2: The Potential Mapping of Land Fire for Environmental Damage Mitigation

\subsection{Data Analysis}

This study used a descriptive method with a survey to observe the research area and collect data ${ }^{2)}{ }^{82)}$. The survey method is a method that aims to collect data from institutions such as hotspot data from SNPP VIIRS 20122021. Hotspot data detected by SNPP VIIRS is used to identify fire activity ${ }^{2}$. Research locations in South 
Kalimantan Province include 13 districts/cities. Population and sample are the distribution of hotspots in 13 districts/cities in South Kalimantan. Research also uses location classification because differences in location result in differences in samples ${ }^{83)}{ }^{84)}$. The difference in the number of hotspots in each area will affect the sample from each sub-district.

The data collected consists of primary data and secondary data. Secondary data collection includes data from the literature, books, journals, research reports, spatial data, and hotspot data. The spatial data is converted into the data format according to the software used in carrying out Geographical Information System (GIS) procedures. Primary data to verify the presence and condition of hotspots that are considered to have the potential to become fire and mitigate environmental damage. Data collection was carried out by involving students as enumerators.

Research variables are aspects that will be studied in research (see Table 1)-data processing techniques using Arc GIS software with scoring, overlay and clustering techniques. The analysis technique used is an analysis of the results of field observations and spatial analysis. Spatial analysis using personal computers (pc), ArcGIS software, GPS, and digital cameras. Spatial analysis to produce a Fire Potential Map in the research area. The hotspot sequence pattern distribution map is processed to create a Fire Potential Map which will be used to provide recommendations in mitigating environmental damage.

The Fire Potential Map is the first step in estimating areas that have the potential for forest/land fires. Hotspot data can be used for the grouping process according to the information held by the data so that potential fires can be identified. The grouping process can be done by implementing the clustering method ${ }^{81)}$. Clustering is a process of grouping records, observations, or grouping classes that have similar objects ${ }^{85)}$. Clustering is carried out to find out which areas have a high potential for fire so that further environmental damage mitigation can be carried out.

Table 1. Research Variables.

\begin{tabular}{|c|l|l|l|}
\hline No. & \multicolumn{1}{|c|}{ Variable } & Sub Variable & \multicolumn{1}{|c|}{ Data Collection } \\
\hline 1. & $\begin{array}{l}\text { The Potential } \\
\text { Mapping Fire }\end{array}$ & $\begin{array}{l}\text { Hotspot, } \\
\text { Potential Fire }\end{array}$ & $\begin{array}{l}\text { Secondary Data, } \\
\text { Mapping and Field } \\
\text { Observation }\end{array}$ \\
\hline 2. & $\begin{array}{l}\text { Environmental } \\
\text { Damage } \\
\text { Mitigation }\end{array}$ & Mitigation & Field observation \\
\hline
\end{tabular}

\section{Result and Discussion}

\subsection{Distribution of Hotspots in 2012-2021}

A hotspot is an indicator of the causes of forest fires, where the surface temperature is relatively higher than the surrounding temperature ${ }^{13)}{ }^{83)}{ }^{86)},{ }^{87)}$, ${ }^{88}$. The satellite will identify a pixel as a hotspot if a pixel has a temperature above the threshold ${ }^{2)}$. The temperature threshold that is identified as a hotspot is when it reaches $>3300 \mathrm{~K}{ }^{89}$. Hotspot data were taken from SNPP VIIRS from 20122021. Hotspot monitoring using satellites is highly dependent on cloud cover, so not all hotspots are monitored by satellite ${ }^{66)}$. In addition, there were sometimes days where data was not collected and days with a lower-than-normal number of fires and due to sensor outages ${ }^{90)}$. There is the possibility of an omission error (there is a fire but no hotspot) and a commission error (there is a hotspot but no fire is detected) ${ }^{91}$.

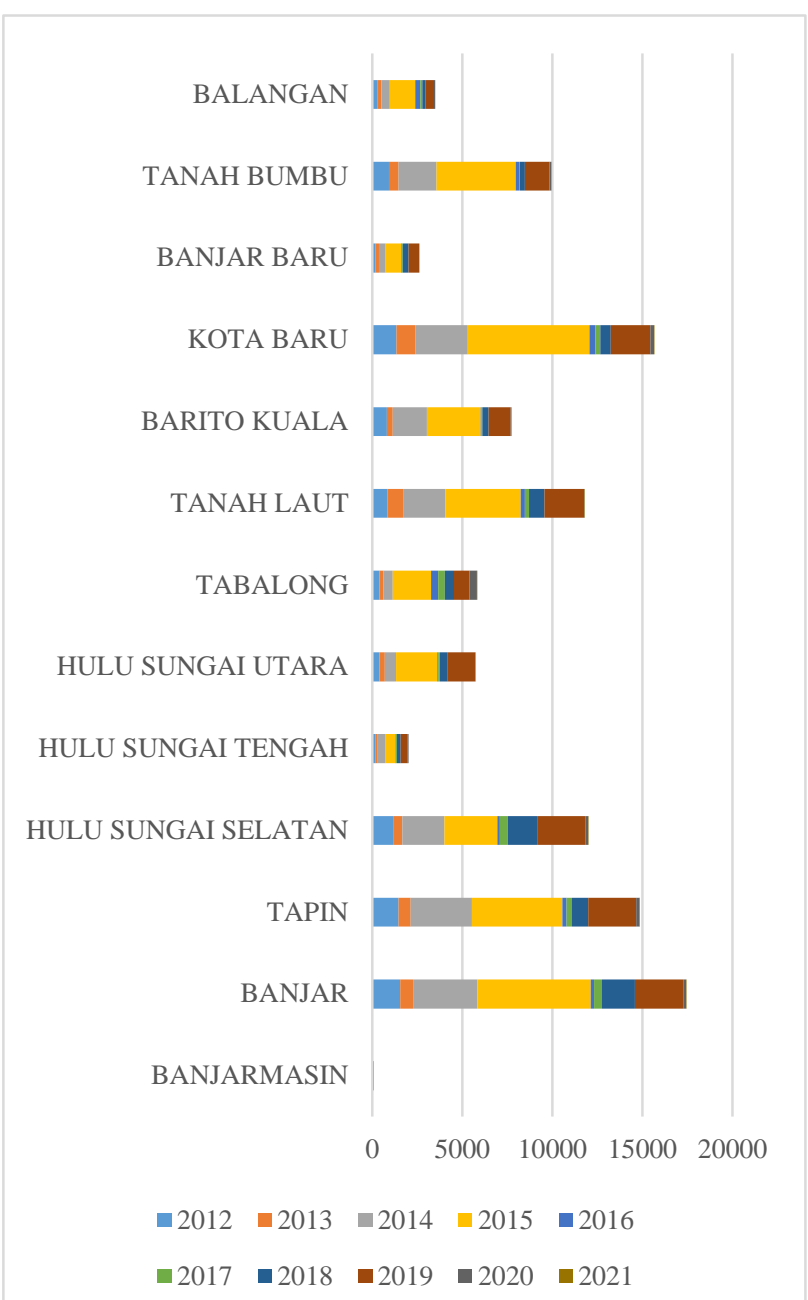

Fig. 3: Frequency and Distribution of Hotspot Distribution from SNPP VIIRS 2012-2021, South Kalimantan Province

Hotspot data from SNPP VIIRS in the study area can be seen in Table 2 and Figure 3. Based on the existing data in South Kalimantan, most of the hotspots are in Banjar Regency with 17428, followed by Kotabaru with 15650, Tapin 14838 hotspots, Hulu Sungai Selatan 11979 hotspots and Tanah Laut with 11787 hotspots. Fires from 2012-2015 continued to increase in all districts/cities. The highest hotspot peak in 2015 due to causing by extreme weather events such as El Nino ${ }^{36)}{ }^{69)}$. El Nino causes prolonged drought so that plants become dry and burn easily. After 2015 the fires started to fall as there were fewer hotspots. 
The number of hotspots in 2019 began to rise again, with the highest number remaining in Banjar Regency (2673).

Hotspots are pixels of high infrared intensity satellite images that indicate a heat source. A hotspot can represent a single hotspot or become one of several hotspots that represent a more significant fire ${ }^{2)}$. The more hotpots found in an area, the higher the potential for fire to occur in that area. Most of the areas in South Kalimantan are found hotspots so that they have the potential for fires. As seen from number of hotspots, the potential for fires continued to increase from 2012-2015, after 2015 had fallen and raise again in 2019.

Table 2. Frequency and Distribution of Hotspot Distribution from SNPP VIIRS 2012-2021, South Kalimantan Province

\begin{tabular}{|l|r|r|r|r|r|r|r|r|r|r|r|}
\hline \multirow{2}{*}{ Districts } & \multicolumn{9}{|c|}{ YEAR } & \multirow{2}{*}{ Amount } \\
\cline { 2 - 11 } & $\mathbf{2 0 1 2}$ & $\mathbf{2 0 1 3}$ & $\mathbf{2 0 1 4}$ & $\mathbf{2 0 1 5}$ & $\mathbf{2 0 1 6}$ & $\mathbf{2 0 1 7}$ & $\mathbf{2 0 1 8}$ & $\mathbf{2 0 1 9}$ & $\mathbf{2 0 2 0}$ & $\mathbf{2 0 2 1}$ & \\
\hline Banjarmasin & 7 & 4 & 15 & 25 & 0 & 0 & 1 & 4 & 0 & 0 & $\mathbf{5 6}$ \\
\hline Banjar & 1561 & 716 & 3554 & 6303 & 179 & 425 & 1840 & 2673 & 176 & 1 & $\mathbf{1 7 4 2 8}$ \\
\hline Tapin & 1459 & 671 & 3391 & 5029 & 240 & 287 & 909 & 2650 & 197 & 5 & $\mathbf{1 4 8 3 8}$ \\
\hline Hulu Sungai Selatan & 1146 & 528 & 2339 & 2924 & 148 & 440 & 1651 & 2648 & 154 & 1 & $\mathbf{1 1 9 7 9}$ \\
\hline Hulu Sungai Tengah & 157 & 144 & 428 & 548 & 27 & 55 & 211 & 390 & 51 & 0 & $\mathbf{2 0 1 1}$ \\
\hline Hulu Sungai Utara & 385 & 313 & 614 & 2306 & 34 & 97 & 449 & 1507 & 17 & 0 & $\mathbf{5 7 2 2}$ \\
\hline Tabalong & 388 & 243 & 504 & 2120 & 405 & 365 & 518 & 838 & 414 & 25 & $\mathbf{5 8 2 0}$ \\
\hline Tanah Laut & 823 & 898 & 2326 & 4188 & 224 & 230 & 869 & 2186 & 38 & 5 & $\mathbf{1 1 7 8 7}$ \\
\hline Barito Kuala & 798 & 325 & 1913 & 2970 & 47 & 55 & 348 & 1228 & 36 & 0 & $\mathbf{7 7 2 0}$ \\
\hline Kota Baru & 1351 & 1029 & 2907 & 6777 & 315 & 266 & 581 & 2211 & 207 & 6 & $\mathbf{1 5 6 5 0}$ \\
\hline Banjarbaru & 187 & 192 & 352 & 884 & 10 & 63 & 329 & 574 & 9 & 0 & $\mathbf{2 6 0 0}$ \\
\hline Tanah Bumbu & 924 & 544 & 2083 & 4414 & 185 & 40 & 287 & 1349 & 106 & 3 & $\mathbf{9 9 3 5}$ \\
\hline Balangan & 291 & 218 & 456 & 1416 & 272 & 129 & 175 & 476 & 53 & 0 & $\mathbf{3 4 8 6}$ \\
\hline Amount & $\mathbf{9 4 7 7}$ & $\mathbf{5 8 2 5}$ & $\mathbf{2 0 8 8 2}$ & $\mathbf{3 9 9 0 4}$ & $\mathbf{2 0 8 6}$ & $\mathbf{2 4 5 2}$ & $\mathbf{8 1 6 8}$ & $\mathbf{1 8 7 3 4}$ & $\mathbf{1 4 5 8}$ & $\mathbf{4 6}$ & $\mathbf{1 0 9 0 3 2}$ \\
\hline
\end{tabular}

Source: Sipongi.menlhk.go.id, 2012-2021; Satelit.bmkg.go.id, 2012-2021; https://earthdata.nasa.gov/earth-observationdata/near-real-time/firms/viirs-i-band-active-fire-data; Processing and Analysis Results, 2021

\subsection{Confidence Hotspot Distribution 2012-2021}

This research is not limited to a certain level of confidence. All hotspot confidence levels were taken in this study. Each visible hotspot will be considered a hotspot or hotspot based on the hotspot appearance area ${ }^{2)}$. Each confidence level provides the highest level of accuracy compared to other data sources; there is a strong correlation in fire detection in the study area from various levels of confidentiality ${ }^{92)}$. The peak appearance of hotspot density for various levels of confidentiality from 2012-2021 in South Kalimantan in 2015 (see Table 3 and Figure 4). 2015 entered the summer season due to the El Nino phenomenon, which caused reduced rainfall in most parts of Indonesia, including South Kalimantan ${ }^{93)}$.

The analysis of the number of SNPP VIIRS image hotspot distribution detected in South Kalimantan based on the value of confidence/level of confidence are at most in confidence $\mathrm{N}$ (Nominal). Nominal confidence at most in each district/city of South Kalimantan Province. Not too much Confidence Hight. Areas that have Nominal and High confidence levels have a high potential for fires. The distribution of hotspots of various confidence levels in South Kalimantan is the highest in Banjar Regency. The number of hotspots in Banjar District shows confidence
Low (L) (1303), Nominal (N) (15444) and High (H) (681). The highest in Banjar Regency is Nominal Confidence, and the least is High Confidence, where confidence $\mathrm{N}$ and $\mathrm{H}$ have a high potential for fires.

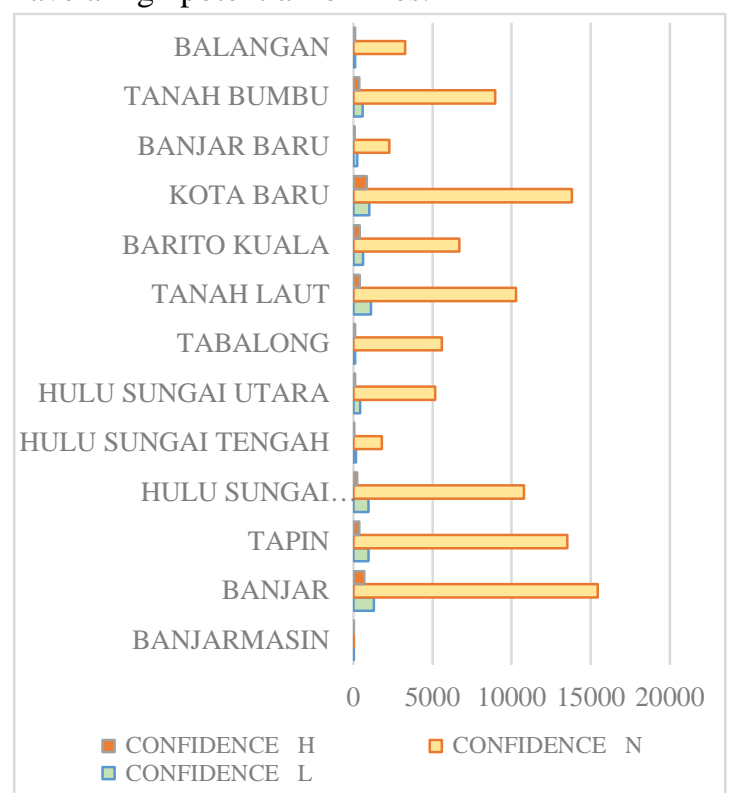

Fig. 4: Confidence Hotspot Distribution from SNPP VIIRS 2012-2021 South Kalimantan Province 
Table 3. Confidence of Hotspot Distribution from SNPP VIIRS 2012-2021, South Kalimantan Province

\begin{tabular}{|l|r|r|r|r|}
\hline \multirow{2}{*}{ DISTRICTS } & \multicolumn{2}{|c|}{ CONFIDENCE } & \multirow{2}{*}{ AMOUNT } \\
\cline { 2 - 4 } & \multicolumn{1}{c|}{ L } & \multicolumn{1}{c|}{ N } & \multicolumn{1}{c|}{ H } & \\
\hline Banjarmasin & 9 & 42 & 5 & 56 \\
\hline Banjar & 1303 & 15444 & 681 & 17428 \\
\hline Tapin & 956 & 13510 & 372 & 14838 \\
\hline Hulu Sungai Selatan & 959 & 10777 & 243 & 11979 \\
\hline Hulu Sungai Tengah & 157 & 1794 & 60 & 2011 \\
\hline Hulu Sungai Utara & 436 & 5165 & 121 & 5722 \\
\hline Tabalong & 109 & 5595 & 116 & 5820 \\
\hline Tanah Laut & 1104 & 10274 & 409 & 11787 \\
\hline Barito Kuala & 622 & 6684 & 414 & 7720 \\
\hline Kota Baru & 994 & 13812 & 844 & 15650 \\
\hline Banjarbaru & 256 & 2269 & 75 & 2600 \\
\hline Tanah Bumbu & 584 & 8967 & 384 & 9935 \\
\hline Balangan & 121 & 3264 & 101 & 3486 \\
\hline \multicolumn{1}{|c|}{ AMOUNT } & $\mathbf{7 6 1 0}$ & $\mathbf{9 7 5 9 7}$ & $\mathbf{3 8 2 5}$ & $\mathbf{1 0 9 0 3 2}$ \\
\hline
\end{tabular}

\subsection{Mapping of Potential Land Fires Using SNPP VIIRS for Mitigation of Environmental Damage}

The distribution of hotspots in each area is influenced by many factors, including vegetation and human activities. Human activities that drive the increasing spread of the number of hotspots are the culture and views of the community with land clearing patterns. Land clearing that is still often done relies on slash and burn during the dry season for agricultural land preparation ${ }^{33}$. The fire phenomenon identified indicates that grass and scrub burnt more frequently than active agricultural land or other land covers. Grass and shrubs burn more often because they have a more delicate structure, so they are more easily burned than different types of combustible materials ${ }^{94)}$, ${ }^{95}$. Fire is still used as a mechanism to open up areas suitable for agriculture. The community's income level is generally relatively low, so clearing land by burning is a fast, easy, inexpensive alternative, and does not require much energy. Seeing this, the relationship between land fires and economic strength seems very strong ${ }^{96)}$. So that there is a relationship between the emergence of continuous hotspots with changes in land use ${ }^{16), 97)}$. The consistent pattern of hotspot occurrence allows land change to continue and the potential for fires to be more significant.

Based on data from findings in the field, most hotspots' locations were in dryland agriculture areas, dryland agriculture mixed with shrubs and bushland areas. The number of hotspots on dryland agriculture from 20122021 was 27614, spread across 13 districts and cities in South Kalimantan Province. Meanwhile, the number of hotspots found in dryland agriculture mixed with shrubs is 16160 , and there are 12881 hotspots in the Bushlands area. Therefore, these three areas have the highest potential for fires.

As the number of hotspots increases, the value of confidence also increases. Satellite image data shows consistency between hotspot shapefile data with data from SNPP VIIRS satellite imagery interpretation and results of field checks. This research uses the overall distribution of hotspot data to assume that hotspots are Spotfire or possible Spotfire ${ }^{98)}$. The utilization of hotspot data from SNPP VIIRS imagery is very significant in managing land and forest fire disaster management, especially for several agencies such as the BPBD, South Kalimantan. Monitoring and evaluating fire trails can be predicted from SNPP VIIRS satellite imagery data by making a map of potential fires and the placement of fire prevention posts. Placement of fire prevention posts in zones considered to have a high potential for land and forest fires, including one form of mitigation carried out (87\%).

Looking at the distribution of various levels of confidence, it can say that most areas in South Kalimantan have a high potential for fires. Banjar Regency is one of the districts with the highest potential, so a Fire Potential Mapping is needed (see Figure 5). Areas that have high potential for fires are Banjar Kotabaru, Tapin, Hulu Sungai Selatan and Tanah Laut districts. The existing Fire Potential Mapping result can be used as a basis for mitigation actions and providing recommendations. Mitigation in fire disaster management reduces the risk of environmental damage in the future (see Table 4).

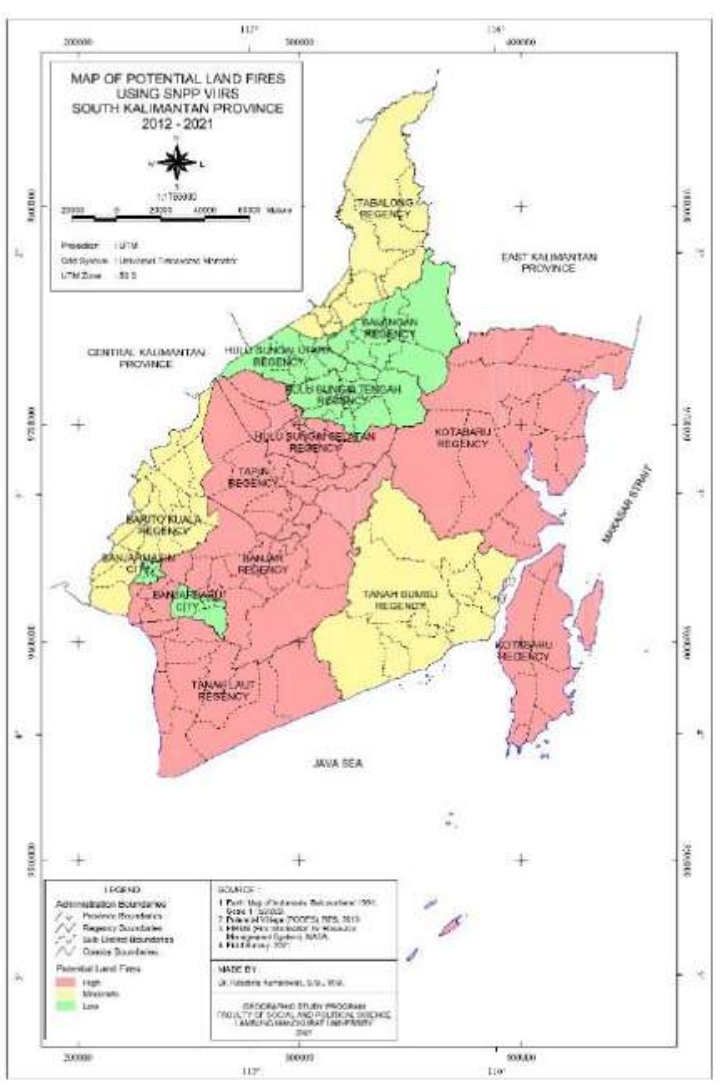

Fig. 5: Map of Potential Land Fires Using SNPP VIIRS 
Table 4. Mitigation of Environmental Damage Due to Fire

\begin{tabular}{|c|c|c|c|c|}
\hline \multicolumn{5}{|c|}{ Disaster } \\
\hline \multicolumn{2}{|c|}{$\begin{array}{c}\text { Environmental } \\
\text { Damage Mitigation }\end{array}$} & Answer & Amount & (\%) \\
\hline \multirow{6}{*}{$\begin{array}{l}\text { Structural } \\
\text { Mitigation }\end{array}$} & \multirow{2}{*}{$\begin{array}{l}\text { Installation of } \\
\text { evacuation route } \\
\text { signs }\end{array}$} & Yes & 90 & 90 \\
\hline & & No & 10 & 10 \\
\hline & \multirow{2}{*}{$\begin{array}{l}\text { Infrastructure } \\
\text { development } \\
\text { (roads) to } \\
\text { facilitate } \\
\text { evacuation routes }\end{array}$} & Yes & 87 & 87 \\
\hline & & No & 13 & 13 \\
\hline & \multirow{2}{*}{$\begin{array}{l}\text { Infrastructure } \\
\text { development in } \\
\text { the form of fire } \\
\text { prevention posts } \\
\text { for fire prevention }\end{array}$} & Yes & 85 & 85 \\
\hline & & No & 15 & 15 \\
\hline \multirow{6}{*}{$\begin{array}{l}\text { Non- } \\
\text { Structural } \\
\text { Mitigation }\end{array}$} & \multirow{2}{*}{$\begin{array}{l}\text { Educate the public } \\
\text { regarding fire } \\
\text { disasters and their } \\
\text { impact on the } \\
\text { environment }\end{array}$} & Yes & 100 & 100 \\
\hline & & No & 0 & 0 \\
\hline & \multirow[b]{2}{*}{$\begin{array}{l}\text { Dissemination of } \\
\text { fire disaster } \\
\text { information to } \\
\text { reduce the risk of } \\
\text { environmental } \\
\text { damage }\end{array}$} & Yes & 100 & 100 \\
\hline & & No & 0 & 0 \\
\hline & \multirow{2}{*}{$\begin{array}{l}\text { Disseminating the } \\
\text { importance of } \\
\text { reforestation and } \\
\text { land rehabilitation } \\
\text { to prevent } \\
\text { environmental } \\
\text { damage from fires }\end{array}$} & Yes & 70 & 70 \\
\hline & & No & 30 & 30 \\
\hline
\end{tabular}

Disaster mitigation is divided into structural mitigation and non-structural mitigation ${ }^{99)}$. Structural mitigation is carried out through physical and infrastructure development efforts to reduce the risk of fire disasters, such as installing evacuation route signs and construction of fire control posts (>80\%). It can also do development through technology development ${ }^{100)}$. Meanwhile, nonstructural mitigation is carried out to raise awareness or education to reduce disaster risk, early warning systems and disaster preparedness communities (100\%). One form of education that can be carried out is, for example, so that people do not burn to clear land. Education must be developed and improved to gain insight into pre-disaster and post-disaster management to minimize the risk of disasters faced ${ }^{101)}$, to minimize future environmental damage due to fires that occur.

Another effort to mitigate environmental damage from the government to reduce fires is by strengthening the role of the mass media for the socialization and dissemination of information on fire disasters $(100 \%)$. Socialization of the importance of reforestation and land rehabilitation is also needed to reduce the risk of environmental damage (70\%). Mitigation to prevent ecological damage due to fire has mainly been carried out in the study area ( $>70 \%)$. The hope is that the community and government will be better prepared for the fires. Detection of fires in peatlands is known more quickly so that prevention and mitigation can be carried out immediately to reduce the risk of fire and environmental damage. Seeing this, the Fire Potential Map is very important and is one form of early detection of potential fires in the future 1),99),24),54).

\section{Conclusion}

Results showed that South Kalimantan has the most hotspots, and the highest is there Banjar Regency. Banjar Regency is an area that has the highest hotspot data of 17428, followed by Kotabaru, Tapin, Hulu Sungai Selatan, and Tanah Laut, respectively are 15650, 14838, 11979 and 11787. The number of hotspot distribution from SNPP VIIRS images detected in South Kalimantan based on the confidence value is most confidence $\mathrm{N}$ (Nominal) of 15444. South Kalimantan has a high potential for fires. Mitigation to prevent environmental damage due to fire has mainly been carried out in the study area (> 70\%), either structural or non-structural mitigation. The results of the Fire Potential Mapping are used as the basis for mitigation actions and providing recommendations for disaster management in reducing the risk of environmental damage in the future.

\section{Acknowledgements}

The authors would like to express their sincere gratitude to Lambung Mangkurat University especially The Institution of Research and Community Service (LPPM) for supporting this study through a research scheme lecturer must research Program (Program Dosen Wajib Meneliti/PDWM) with a contract number 009.14/UN8.2/PL/2021.

\section{References}

1) S. Ramadhanty, M.H. Amirullah, M.H. Faturrahman, R. Dhelika, and T. Abuzairi, "Development of small scale electrohydrodynamic drying device for rough rice using dc plasma generator," Evergreen, 6 (2) 103-107 (2019). doi:10.5109/2321000.

2) A.G. Alam, Nasruddin, A. Tirta, and C.K. Priambada, "Building beneficial roof insulation in vertical housing: physical and economical selection method," Evergreen, $6 \quad$ (2) 124-133 (2019). doi:10.5109/2321006.

3) F. Rasyid, "Problems and impacts of forest fires" $J$. Lingk. Widyaiswara, (4) 47-59 (2014). http://juliwi.com/published/E0104/Paper0104_47- 
59.pdf.

4) N. Bhasin, R.N. Kar, and N. Arora, "Green disclosure practices in india: a study of select companies," Evergreen, 2 (2) 5-13 (2015). doi:10.5109/1544075.

5) M.W. Shahzad, K. Thu, B.B. Saha, and K.C. Ng, “An emerging hybrid multi-effect adsorption desalination system,” Evergreen, 1 (2) 30-36 (2014). doi:10.5109/1495161.

6) Martell DL, "(2001). Forest Fire Management. In: Forest Fires- Behaviour and Ecological Effects," Johnson EA, Academic Press, New York, 2001.

7) I. Koren, and G. Feingold, "Aerosol-cloudprecipitation system as a predator-prey problem," Proc. Natl. Acad. Sci. U. S. A., 108 (30) 12227-12232 (2011). doi:10.1073/pnas.1101777108.

8) J. Schweithelm, and D. Glover, "Causes and Impacts of Fire in the High Cost of a Disaster: Environmental Losses Due to Fire and Haze in Indonesia". 1999.

9) Achmad T. Nugraha, Gunawan Prayitno, Abdul W. Hasyim, and Fauzan Roziqin, "Social capital, collective action, and the development of agritourism for sustainable agriculture in rural indonesia," Evergreen, 8 (1) 1-12 (2021). doi:10.5109/4372255.

10) M. Zhong, W. Fan, T. Liu, and P. Li, "Statistical analysis on current status of china forest fire safety," Fire Saf. J., 38 (3) 257-269 (2003).

11) H. Ayberk, A. Kucukosmanoglu, and H. Cebeci, "The structure and importance of fire suppressing organizations in turkey," Sci. Res. Essays, 5 (5) 456460 (2010).

12) M.A.A. Wahid, M.J. Megat Mohd Noor, and H. Hara, "Recombinant moringa oleifera lectin produced in pichia pastoris is a potential natural coagulant," Evergreen, 3 (2) 11-16 (2016). doi:10.5109/1800867.

13) H. Jayawardana, "Environmental care character education from an early age as an effort to mitigate ecological disasters" Symbion (Symposium Biol. Educ., $\quad 5726 \quad 49-64 \quad$ (2016). http://symbion.pbio.uad.ac.id/prosiding/prosiding/ID _276_Hepta_Revisi_Hal 49-64.pdf.

14) M. Pasai, "forest fires and law enforcement". J. Chem. Inf. Model., 21 (1) 1-9 (2020). https://doi.org/10.1016/j.tmaid.2020.101607\%0Ahtt ps://doi.org/10.1016/j.ijsu.2020.02.034\%0Ahttps://o nlinelibrary.wiley.com/doi/abs/10.1111/cjag.12228\% 0Ahttps://doi.org/10.1016/j.ssci.2020.104773\%0Aht tps://doi.org/10.1016/j.jinf.2020.04.011\%0Ahttps://d oi.o.

15) Y.W. Utomo, "Earth day and sad facts about Indonesian nature alam" (2015).

16) M. Ardiansyah, R. Boer, and A.P. Situmorang, "Preface: international conference on recent trends in physics (icrtp 2016)," IOP Confrence Ser. Earth Environ. Sci., 54 (2017). doi:10.1088/17426596/755/1/011001.

17) T.A. Rivai, K. Yonezu, Syafrizal, and K. Watanabe, "Mineralogy and geochemistry of host rocks and orebodies at the anjing hitam prospect (dairi, north sumatra, indonesia) and their environmental implications," Evergreen, 6 (1) 18-28 (2019). doi:10.5109/2320997.

18) Masganti, "Innovative Technology for suboptimal land management of peat and acid sulphate to increase food crop production" Pengemb. Inov. Pertan., 6 (4) 187-197 (2013).

19) H.W. Masganti, Nurhayati, Rachmiwati Yusuf, "Environmentally friendly technology in oil palm cultivation on degraded peatlands" Sumber Daya Lahan, Vol. 9 No. (2) 97-106 (2015). http://ejurnal.litbang.pertanian.go.id/index.php/jsl/ar ticle/view/6594/5855.

20) R.Y. Masganti, Wahyunto, Ai Dariah, Nurhayati, "Characteristics and potential utilization of degraded peatlands in riau province,” J. Sumberd. Lahan, 8 (1) 59-66 (2014).

21) K. Nugroho, and B. Widodo, "Effect of dry - wet condition to peat soil physical characteristics of different degree of decomposition,” in: Int. Symp. Trop. Peatlands, BPPT, Jakarta (Indonesia), 2002.

22) Masganti, "Sample preparation for peat material analysis. Pp . In Husein et al. (Eds.).," in: Pros. Work. Sustain. Manag. Lowl. Rice Prod., 2012: pp. 179-184.

23) $\mathrm{C}$. $\mathrm{Li}$, and K. Ito, "Performance evaluation of industrial air-shower in removal of gas- and liquidphase contaminants from human body,” Evergreen, 1 (1) 40-47 (2014). doi:10.5109/1440976.

24) M. Umar, S. Atif, M.L. Hildebrandt, A. Tahir, M. Azmat, and M. Zeeshan, "Trends of aerosol optical thickness using viirs s-npp during fog episodes in pakistan and india," Atmosphere (Basel)., 12 (2) 1-16 (2021). doi:10.3390/atmos12020242.

25) N.A. Lestari, "Reduction of co2 emission by integrated biomass gasific ation-solid oxide fuel cell combined with heat recovery and in-situ co2 utilization," Evergreen, 6 (3) 254-261 (2019). doi:10.5109/2349302.

26) K.L. Chan, and K.L. Chan, "Aerosol optical depths and their contributing sources in taiwan," Atmos. Environ., $148 \quad 364-375 \quad$ (2017). doi:10.1016/j.atmosenv.2016.11.011.

27) B.R. Gurjar, T.M. Butler, M.G. Lawrence, and J. Lelieveld, "Evaluation of emissions and air quality in megacities," Atmos. Environ., 42 (7) 1593-1606 (2008). doi:10.1016/j.atmosenv.2007.10.048.

28) I. Koren, O. Altaratz, L.A. Remer, G. Feingold, J.V. Martins, and R.H. Heiblum, "Aerosol-induced intensification of rain from the tropics to the midlatitudes,” Nat. Geosci., 5 (2) 118-122 (2012). doi:10.1038/ngeo1364.

29) C.A. Pope III, R.T. Burnett, M.J. Thun, E.E. Calle, D. Krewski, and G.D. Thurston, "To fine particulate air pollution,” J. Am. Med. Assoc., 287 (9) 1132-1141 (2002). http://jama.jamanetwork.com/article.aspx?doi=10.10 
01/jama.287.9.1132.

30) S.P. Dwivedi, M. Maurya, N.K. Maurya, A.K. Srivastava, S. Sharma, and A. Saxena, "Utilization of groundnut shell as reinforcement in development of aluminum based composite to reduce environment pollution: a review,” Evergreen, 7 (1) 15-25 (2020). doi:10.5109/2740937.

31) Endrawati, "Data Analysis of Hotspots and Forest and Land Fires Areas in 2016". https://rfmrc-sea.org/wpcontent/uploads/2015/01/Analisis-Data-Titik-PanasHotspot-dan-Areal-Kebakran-Hutan-dan-LahanTahun-2016.pdf.

32) S. Sawerah, P. Muljono, and P. Tjitropranoto, "Community participation in preventing peatland fires in Mempawah Regency, West Kalimantan Province" J. Penyul., $12 \quad$ (1) (2016). doi:10.25015/penyuluhan.v12i1.11323.

33) S.S. Adam, M.G. Rindarjono, and P. Karyanto, "Geographic information system for vulnerability zoning of land and forest fire in malifut sub-district , north halmahera," J. Teknol. Inf. Dan Ilmu Komput., 6 (5) 559-566 (2019). doi:10.25126/jtiik.201961674.

34) A.S. Keraf, "Environmental ethics" Kompas, 322 (2002).

35) W.Y.W. Mahmood, and A.H. Mohammed, “A conceptual framework for the development of quality culture in the construction industry," Assoc. Res. Constr. Manag. ARCOM 2008 - Proc. 24th Annu. Conf., 1 (September) 247-256 (2008).

36) R. Andhika, and Y. Latief, “Conceptual framework of development of quality culture in indonesian construction company,” Evergreen, 7 (1) 144-149 (2020). doi:10.5109/2740971.

37) M.J. Wooster, G. Roberts, G.L.W. Perry, and Y.J. Kaufman, "Retrieval of biomass combustion rates and totals from fire radiative power observations: frp derivation and calibration relationships between biomass consumption and fire radiative energy release,” J. Geophys. Res. Atmos., 110 (2005).

38) M.J. Wooster, G.L.W. Perry, and A. Zoumas, "Fire, drought and el niño relationships on borneo during the pre-modis era (1980-2000)," Biogeosciences Discuss., 8 (1) 975-1013 (2011). doi:10.5194/bgd-8975-2011.

39) C.D. Elvidge, D. Ziskin, K.E. Baugh, B.T. Tuttle, T. Ghosh, D.W. Pack, E.H. Erwin, and M. Zhizhin, “A fifteen year record of global natural gas flaring derived from satellite data,” Energies, 2 (3) 595-622 (2009). doi:10.3390/en20300595.

40) M. Zhizhin, C.D. Elvidge, F.C. Hsu, and K.E. Baugh, "Using the short-wave infrared for nocturnal detection of combustion sources in viirs data," Proc. Asia-Pacific Adv. Netw, 35 49-61 (2013).

41) H.L. Fitriana, S. Sulma, N. Suwarsono, A. Zubaidah, and I. Prasasti, "Spectral analysis of the himawari-8 data for hotspot detection from land/forest fires in sumatra,” Int. J. Remote Sens. Earth Sci., 15 (1) 15
(2018). doi:10.30536/j.ijreses.2018.v15.a2836.

42) Y.J. Kaufman, C.O. Justice, L.P. Flynn, J.D. Kendall, E.M. Prins, L. Giglio, D.E. Ward, W.P. Menzel, and A.W. Setzer, "Potential global fire monitoring from eos-modis,” J. Geophys. Res. Atmos., 103 (D24) 32215-32238 (1998). doi:10.1029/98JD01644.

43) L. Giglio, J.D. Kendall, and C.O. Justice, “Evaluation of global fire detection algorithms using simulated avhrr infrared data,” Int. J. Remote Sens., 20 (10) 1947-1985 (1999). doi:10.1080/014311699212290.

44) C.O. Justice, L. Giglio, S. Korontzi, J. Owens, J.T. Morisette, D. Roy, J. Descloitres, S. Alleaume, F. Petitcolin, and Y. Kaufman, "The modis fire products," Remote Sens. Environ., 83 (1-2) 244-262 (2002). doi:10.1016/S0034-4257(02)00076-7.

45) ESDIS, "Fire Information for Resource Management System (FIRMS). NASA's Goddard Space Flight Center/Earth Science Data and Information System (ESDIS)," 2005.

46) I. Prasasti, N. Suwarsono, F. Yulianto, S. Sulma, jalu tejo Nugroho, and K.I.I. Rahmi, "Utilization of remote sensing satellite data for mangrove mapping" 5 (2) 3-6 (2018). www.lapan.go.id.

47) R. Kumalawati, Salamiah, A. Yuliarti, and K.H. Murliawan, "Potential mapping agricultural commodities to mitigation of food problem in the future," Geoj. Tour. Geosites, 33 (4) 1480-1485 (2021). doi:10.30892/gtg.334spl05-596.

48) R.E. Wolfe, M. Nishihama, G. Lin, K.P. Tewari, and E. Montano, "MODIS and viirs geometric performance comparison," IEEE Int. Geosci. Remote Sens. Symp., 5017-5020 (2012). doi:https://doi.org/10.1109/IGARSS.2012.6352484.

49)A.K. Verma, "MODELLING fire hazard in pine zone," (September 2017) (2018).

50) L. Giglio, "MODIS collection 4 active fire product user's guide version 2 . 3," Sites J. 20Th Century Contemp. French Stud., Version 2. (February) 44 (2007). http://maps.geog.umd.edu/products/MODIS_Fire_U sers_Guide_2.3.pdf.

51) I. Ibáñez, J.A. Silander, J.M. Allen, S.A. Treanor, and A. Wilson, "Identifying hotspots for plant invasions and forecasting focal points of further spread," $J$. Appl. Ecol., $46 \quad$ (6) 1219-1228 (2009). doi:10.1111/j.1365-2664.2009.01736.x.

52) A.. Thoha, "Application of remote sensing on peat fire detection in bengkalis district riau province, peronema forestry science journal," Peronema For. Sci. J., 2 (2) (2006).

53) J. Han, M. Kamber, and J. Pei, "Third edition : data mining concepts and techniques," J. Chem. Inf. Model., $53 \quad$ (9) 1689-1699 (2012). http://library.books24x7.com/toc.aspx?bkid=44712.

54) J.C. Bezdek, and N.R. Pal, "Some new indexes of cluster validity,” IEEE Trans. Syst. Man, Cybern. Part B Cybern., 28 (3) 301-315 (1998). 
doi:10.1109/3477.678624

55) R. Kumalawati, Nasruddin, and rizky nurita Anggraeni, "Mapping the distribution of aqua and terra fashionable data hotspots] 6 (April) (2021).

56) S. Choommanivong, W. Wiriya, and S. Chantara, "Transboundary air pollution in relation to open burning in upper southeast asia," EnvironmentAsia, 12 (Special Issue) 18-27 (2019). doi:10.14456/ea.2019.59.

57) A. Pal, K. Uddin, K. Thu, and B.B. Saha, "Environmental assessment and characteristics of next generation refrigerants," Evergreen, 5 (2) 58-66 (2018). doi:10.5109/1936218.

58) N. Anggraini, and B. Trisakti, "Study of the impact of climate change on the province of West Kalimantan" J. Pengideraan Jauh, 8 11-20 (2011).

59) H. Elserafy, "Assessment of demo reactors for fusion power utilization,” Evergreen, 5 (4) 18-25 (2018). doi:10.5109/2174854.

60) S. Kitjanukit, "Attitude toward bioremediationrelated technology and relation with company social responsibility,” Evergreen, 6 (3) 240-245 (2019). doi:10.5109/2349300.

61) D.M. Abouelella, S.E.K. Fateen, and M.M.K. Fouad, "Multiscale modeling study of the adsorption of co2 using different capture materials,” Evergreen, 5 (1) 43-51 (2018). doi:10.5109/1929729.

62) H. Akamine, M. Mitsuhara, and M. Nishida, "Developments of coal-fired power plants: microscopy study of fe-ni based heat-resistant alloy for efficiency improvement," Evergreen, 3 (2) 45-53 (2016). doi:10.5109/1800871.

63) Syafrudin, Mochamad Arief Budihardjo, Nany Yuliastuti, and Bimastyaji Surya Ramadan, "Assessment of greenhouse gases emission from integrated solid waste management in semarang city, central java, indonesia,” Evergreen, 8 (1) 23-35 (2021). doi:10.5109/4372257.

64) D. Mahmoud, and G. Gamal, "THE potential impact of climate change on hurghada city, egypt, using tourism climate index," 25 (2) 496-508 (2019).

65) S.H. Sitorus, and R. Hidayat, "Forest and land fire mitigation strategy through community empowerment in Pakning River, Bengkalis Regency, Riau Province" Int. Conf. Commun. Sos. Sci., 1 (1) (2020). http://sipongi.menlhk.go.id.

66) A. Hoscilo, S.E. Page, K.J. Tansey, and J.O. Rieley, "Effect of repeated fires on land-cover change on peatland in southern central kalimantan, indonesia, from 1973 to 2005," Int. J. Wildl. Fire, 20 (4) 578588 (2011). doi:10.1071/WF10029.

67) M.E. Cattau, M.E. Harrison, I. Shinyo, S. Tungau, M. Uriarte, and R. DeFries, "Sources of anthropogenic fire ignitions on the peat-swamp landscape in Kalimantan, Indonesia," Glob. Environ. Chang., 39 205-209 https://doi.org/10.1016/j.gloenvcha.2016.05.005.
68) A.A.B.A.M. Fadlilatul, and A.F. Hidayatullah, "Forest and land fires environmental ethics Perspective” Profetika, 20 (2) 124-132 (2019).

69) L. Tacconi, "Preventing fires and haze in southeast asia," Nat. Clim. Chang., 6 (7) 640-643 (2016).

70) A. Rezainy, L. Syaufina, and I.S. Sitanggang, "Mapping of fire-prone areas on peatlands based on the pattern of hotspots in the district of Central Kalimantan" J. Pengelolaan Sumberd. Alam Dan Lingkung. (Journal Nat. Resour. Environ. Manag., 10 (1) 66-76 (2020). doi:10.29244/jpsl.10.1.66-76.

71) V.-T. Caciuc, "Ecocentric reflections on the realization of environmental education," Procedia Soc. Behav. Sci., $137 \quad 93-99$ (2014). doi:10.1016/j.sbspro.2014.05.258.

72) M.D. Flannigan, B.D. Amiro, K.A. Logan, B.J. Stocks, and B.M. Wotton, "Forest fires and climate change in the 21st century," Mitig. Adapt. Strateg. Glob. Chang., 11 (4) 847-859 (2006). doi:10.1007/s11027-005-9020-7.

73) P. Cortez, and A. Morais, "A data mining approach to predict forest fires using meteorological data," Proc. 13th Port. Conf. Artif. Intell., 512-523 (2007). http://www.dsi.uminho.pt/ pcortez/fires.pdf.

74) E. Chuvieco, I. Aguado, S. Jurdao, M.L. Pettinari, J. Yebra, M., Salas, and F.J. (2014) Martínez-Vega, "Integrating geospatial information into fire risk assessment,” Int. J. Wildl. Fire, 23 (5) 606-619 (2014). doi:https://doi.org/10.1071/WF12052.

75) A. Mukti, L.B. Prasetyo, and S.B. Rushayati, "Mapping of fire vulnerability in alas purwo national park,” Procedia Environ. Sci., 33 290-304 (2016). doi:10.1016/j.proenv.2016.03.080.

76) dan G.D. Mapilata, Eko., Komarsa Gandasasmita, "Analysis of areas prone to forest and land fires in spatial planning in the city of Palangkaraya, Central Kalimantan province" Globe, 15 (2) 178-184 (2013).

77) S. Samsuri, I.N.S. Jaya, and L. Syaufina, "Spatial model of forest and land fire susceptibility level (Case Study of Central Kalimantan Province" For. Indones. J. For., 1 12-18 (2012).

78) Setiawan, I., A.R. Mahmud, S. Mansor, A.M. Shariff, and A.A. Nuruddin, "GIS-grid-based and multicriteria analysis for identifying and mapping peat swamp forest fire hazard in pahang, malaysia," Disaster Prev. Manag. An Int. J., 13 (5) 379-38 (2004).

79) L. Giglio, J. Descloitres, C.O. Justice, and Y.J. Kaufman, "An enhanced contextual fire detection algorithm for modis," Remote Sens. Environ., 87 (23) 273-282 (2003). doi:10.1016/S00344257(03)00184-6.

80) I. Prasasti, R. Boer, M. Ardiansyah, A. Buono, L. Syaufina, and Y. Vetrita, "Analyzis of relationship between hotspot, fdrs and burned area in central kalimantan,” J. Nat. Resour. Environ. Manag., 2 (2) 91-101 (2012). doi:10.19081/jpsl.2012.2.2.91. 
81) D.F. Pramesti, Lahan, M. Tanzil Furqon, and C. Dewi, "Implementation of the k-medoids clustering method for data grouping" J. Pengemb. Teknol. Inf. Dan Ilmu Komput., $\quad 1 \quad$ (9) 723-732 (2017). doi:10.1109/EUMC.2008.4751704.

82) A. Putra, A.T. Ratnaningsih, and M. Ikhwan, "Mapping of areas prone to forest and land fires using a geographic information system (case study: Bukit Batu subdistrict, Bengkalis Regency)" Wahana For. J. Kehutan., $13 \quad$ (1) 55-63 (2018). doi:10.31849/forestra.v13i1.1555.

83) E. Kumalawati, Rosalina. Dianita Anjarini, “Causes of forest and peatland fires in Barito Kuala Regency, South Kalimantan Province" Pros. Semin. Nas. Diselenggarakan Pendidik. Geogr. FKIP UMP, 1 (1) 263-275 (2019).

84) O. Ozdemir, and A. Morone, "Risk management decisions in low probability and high loss risk situations: experimental evidence," Space.Luiss.It, 131 (2009). http://space.luiss.it/prin2007/bari5.pdf.

85) D.T. Larose, and C.D. Larose., "Discovering knowledge in data: an introduction to data mining.," 4th ed., John Wiley \& Sons, 2014.

86) T. Turmudi, P. Kardono, P. Hartanto, and Y. Ardhitasari, "Forest and land fire prevention through the hotspot movement pattern approach," IOP Conf. Ser. Earth Environ. Sci., 123 (1) (2018). doi:10.1088/1755-1315/123/1/012027.

87) R. Kumalawati, and E. Nasruddin, "Hotspot handling strategy to prevent fires in Barito Regency, Kuala Lumpur, South Kalimantan" Semin. Nas. Lingkung. Lahan Basah, 4 (2) 351-356 (2019).

88) H.R. R., "PIPER no.24 volume 13 april 2017 61,” Piper, $24 \quad$ (24) 69-75 (2017). http://jurnal.unka.ac.id/index.php/piper/article/view/ 69.

89) O. Roswintiarti, "Information on forest/land fire hotspots" (2016).

90) FIRMS, "FIRMS, 'firms frequently asked questions,' nasa,” (2018). https://earthdata.nasa.gov/faq.

91) A. Zubaidah, Y. Vetrita, and R. Khomarudin, "MODIS hotspot validation over sumatra and kalimantan based on remote sensing data spot-4 in 2012.,” J. Penginderaan Jauh, 11 1-14 (2014).

92) Y. Vetrita, A. Zubaidah, M. Priyatna, and K.D.. Sukowati, "Validation of hotspots in fire-prone areas in 2012: cases of peatlands and small fires" Semin. Nas. Penginderaan Jauh, 491-497 (2014). http://sinasinderaja.lapan.go.id/files/sinasja2014/pro siding/bukuprosiding_491-497.pdf.

93) M.B.R. Prayoga, A. Yananto, and D.A. Kusumo, "Analysis of the correlation between hotspot density and rainfall on the islands of Sumatra and Kalimantan" J. Sains Teknol. Modif. Cuaca, 18 (1) 17 (2017). doi:10.29122/jstmc.v18i1.2037.

94) M. C, "Peatland loss could emit 2,800 years' worth of carbon in an evolutionary eyeblink: study,” (2005). http://blog.cifor.org/26254/indonesia-peatlandforest-carbon-emissionsmodel\#.VTd5gZMnJp4?utm_source=RD\&utm_med ium=inart\&utm_campaign=khiprd (accessed March 7, 2021).

95) Samsuri, "Spatial model of forest and land fire susceptibility (case study in Central Kalimantan Province" 2008.

96) L.T. Solichin, P. Kimman, B. Firman, and R. Bagyono, "Mapping of Fire Prone Areas. South Sumatra Forest Fire Management Project (SSFFM)" 2007.

97) H.A. Januarisky, "Distribution Pattern of Hotspots and Their Relation to Land Use Change (Case Study: West Kalimantan Province)" Institut Pertanian Bogor, 2012.

98)GFWF, “Analyze forest fire,” global forest watch fire,” (2019).

99) N. Wahyuningtyas, A. Tanjung, I. Idris, and K. Dewi, "Disaster mitigation on cultural tourism in lombok, indonesia,” Geoj. Tour. Geosites, 27 (4) 1227-1235 (2019).

100) T.R. Wulan, W. Ambarwulan, D.S. Wahyuningsih, E. Maulana, T. Raharjo, F. Ibrahim, M.D. Putra, Z. Setyaningsih, and E.I. Megawati, “Tourism potentialbased disaster mitigation: a case study of Pandawa Beach, Kutuh Village, South Kuta District, Badung Regency" Pros. Semin. Nas. Kelaut. 2016, (Juli) 261266

(2016). https://www.researchgate.net/publication/309555791.

101) E. Orhan, "Building community resilience: business preparedness lessons in the case of adapazari, turkey," Disasters, $40 \quad$ (1) 45-64 (2016). doi:10.1111/disa.12132.

102) Simanjuntak, K. P. and Khaira, U. (2021) 'Grouping of Hotspots in Jambi Province with the Agglomerative Hierarchical Clustering Algorithm", MALCOM: Indonesian Journal of Machine Learning and Computer Science, 1(April), pp. 7-16. Available at:

https://journal.irpi.or.id/index.php/malcom/article/vi ew/6. 